\title{
Lençois esquecidos no Rio Vermelho intervenção urbana
}

SELMA PARREIRA

Resumo

Procurarei fotos das lavadeiras de roupa no Rio Vermelho,da cidade de Goiás , Go , nas coleções particulares e arquivos de museus. Através de elementos da paisagem vou verificar o local onde a fotografia foi realizada e num segundo momento buscarei dados com antigas lavadeiras sobre seu trabalho, hoje extinto. Realizarei intervenção urbana na cidade, remontando nos locais identificados pelas fotos, imagens que restabeleçam no presente uma cena do passado. A nova paisagem resultante será fotografada, documentando esta proposta visual. 